\section{演題 8}

\section{高纴酸素治療の経験}

\section{大阪大学整形外科 水野祥太郎・小沢 告 郎} 昖本有渠・北脇哲雄

昨年基以来, 四肢の末梢動豚閉塞症や細菌感染創な ど的30症例に対し高圧酸素治療を行なっているが，そ の経験について述べる.

\section{演題 9}

\section{嫌気性菌感染症に対する 高圧酸素治療}

\section{東京大学中央手術部 悬 大順・高木忠信 胸部外科 古田昭一・佐藤富藏 麻酔 科 山村秀夫 放射線科 亘理 勉 保健学科 山本俊一・長谷川斐子}

動物を用いて嫌気性菌感染に対する高圧酸素治療実 験を行なった。

Cl. novyi 菌体を試験管内および生体内で加圧すれ ばかなりの効果があるが，同菌の毒素化対しては全く 無効であった．しかし，抗毒素により毒素を中和寸れ ば高圧酸素の効果が現われてくる。

破傷風菌に対する高压酸素の治療効果は, Cl. novyi におけるよりも劣ることが室を用いての実験からかか った.

\section{質問}

\section{演 題 9}

\section{東京医科歯科大学 中央手術部 古橋 正吉}

(1)Contamination の問題は高圧酸素室にはないであ ろらか.もしあるとするならばその対策方法をご教示 願いたい.

(2)Anaerobie. B に対しては絶対に Contamination はおこらないと考えてよろしいか

(3)新鮮火傷などの爆露時など種々の感染の機会が起 こる危険もあるがこの点いかがですか，

(4)高圧室内の消毒方法はどんな方法がよろしいか.
回答

演 題 9

東京大学保健学科 山本俊 -

(1)高圧酸素下で好気性菌の発育が促進されるといら ことはないので，特にその感染に留意する必要はない と思うが，むしろ嚬回加圧による生体抵抗力の低下に 対処することが問題である.

演題 10

\section{嫌気性菌感染症に対する OHP の経験}

\section{東京慈恵会医科大学 綿貫外科 \\ 伊坪喜八郎・田狊 恒・齐藤一夫 宮本満之・戸谷修二小少山一男 望月宣明・伊藤善一・児玉東策

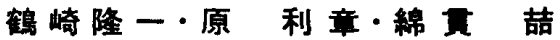

我々は嫌気性菌感染症の内, ガス壊疸 3 例，破傷風 1 例に OHP を忘用したのでその結果を報告する. ガ 又壊痓 3 例はいずれも交通外稘によるもので 2 例は下 腿複雑骨折からの感染と考えられ，ショック状態で来 院し, 抗ショック療法，抗毒素血清，抗生剤を投与後 直ちに大腿骨中央部より切断, 切断後 OHP を施行し た. 第 3 例は下腿の栓創で筇膜損傷を伴なっている。

これも約48時間後に完全なショック状態で来院した。 この例は抗ショック療法などを行なった後，皮膚及び 筋肉に切開創を加えたのみにて OHP を行なって，一 応無菌状態となしえたと思われたが膝部より下は壊死 より回復せず，約 1 週間後切断の止むなきに至った.

破傷風 1 例は onset time 短かく，初期より危険を 予想されたが，高熱を発し，心搏弱くなり，いよいよ 治潦に窮したため OHP を施行してみたが，効なく死 亡した.

追加

演 題 9,10

\section{札幌医大胸部外科 池田晃治・西村 進}

広沉熱傷に対する OHP 疾法の治験より，われわれ は開放㙩法を試みてきたが，一般に感染は問題になら ないようであったが，ただ乾燥受傷面に Fungi の発 育をみた，無害と考えられ放置されていたが，最近で は紫外線照射を試みている。 